\title{
Global Warming Mitigation through the Local Action of Environmental Education in the Plantation Area of Palm Oil
}

\author{
Siti Badriyah Rushayati*, Rachmad Hermawan, Resti Meilani \\ Department of Forest Resources Conservation and Ecotourism \\ Faculty of Forestry, Institut Pertanian Bogor, Kampus IPB Darmaga, Bogor \\ * Corresponding author (e-mail: rus_badriyah@yahoo.co.id)
}

Received: 11 April 2017 / Accepted: 14 July 2017 / Published: 21 July 2017

\begin{abstract}
Oil palm is a strategic mainstay product with a crucial role in the national economy, and it can also be carbon sink to mitigate the negative impact of global warming when managed in environmentally friendly manner. Therefore, management and surrounding community need to have an understanding of the environment, and pro-environmental attitude and behaviour. Action research, which aimed at mitigating global warming through the local action of environmental education (EE), was conducted toward oil palm plantation employee and surrounding community. The EE programme was expected to be able to shape understanding and pro-environmental attitude and behaviour in the target group. Rapid observation and interview were carried out in collecting data for EE programme development. A needs assessment was conducted in developing the EE subject; based on local environmental problems and gap of target group's perception of the problems. Global warming-related environmental problems found in the location included air temperature increase, drought and difficulty in determining planting season. Spatial analysis based on 1989 and 2014 satellite imagery showed a decrease of the water body, tree vegetated land and open areas, and an increase in non-tree vegetated land and built land, accompanied by an increase in areas with higher temperature range. Both employees and the community had a good knowledge of the environment, but less in conservation. The environmental education provided for them had been able to increase their perception on environmental conservation. However, repetition and intensive assistance are still needed to strengthen the perception.
\end{abstract}

Keywords: community, employee, environmental education, global warming mitigation, increase in perception, students.

Abstrak. Kelapa sawit merupakan produk andalan strategis yang mempunyai peran sangat penting dalam perekonomian nasional, serta dapat menjadi rosot karbon yang dapat mengurangi dampak negatif pemanasan global apabila dikelola dengan ramah lingkungan. Untuk itu, pengelola dan masyarakat sekitar perlu memiliki pemahaman, sikap, dan perilaku ramah lingkungan. Action research dengan tujuan melakukan mitigasi pemanasan global melalui kegiatan lokal pendidikan lingkungan di sekitar perkebunan kelapa sawit dilakukan dalam penelitian ini, dengan harapan dapat membentuk pemahaman, sikap dan perilaku ramah lingkungan. Rapid observation dan wawancara dilakukan untuk mengumpulkan data yang dibutuhkan untuk mengembangkan program pendidikan lingkungan. Uji kebutuhan dilakukan untuk mengembangkan materi pendidikan lingkungan, yaitu berdasarkan permasalahan 


\begin{abstract}
lingkungan yang ditemukan di lokasi, serta kesenjangan persepsi kelompok sasaran terkait permasalahan tersebut. Permasalahan lingkungan terkait pemanasan global yang ditemukan di sekitar lokasi penelitian berupa pemanasan udara, kekeringan, serta kesulitan penentuan musim tanam. Analisis spasial berdasarkan citra tahun 1989 dan 2014 menunjukkan adanya penurunan luas badan air, vegetasi pohon, dan lahan terbuka, serta peningkatan vegetasi non pohon dan lahan terbangun, yang diiringi dengan peningkatan luas area dengan kisaran suhu yang lebih tinggi. Karyawan perusahaan maupun masyarakat sebelumnya sudah memiliki pengetahuan yang cukup baik mengenai lingkungan, namun wawasan tentang konservasi masih kurang. Pendidikan lingkungan yang diberikan mampu meningkatkan persepsi responden mengenai konservasi lingkungan, namun perlu ada pengulangan dan pendampingan untuk memperkuat persepsi tersebut.
\end{abstract}

Kata Kunci: karyawan, masyarakat, mitigasi pemanasan global, pendidikan lingkungan, peningkatan persepsi, siswa.

\section{Introduction}

Oil palm plantation sub-sector is one of the main economic mainstays of the nation. According to the Directorate General of Plantation (2014), the area of oil palm plantation in Indonesia in 2013 is 10.01 million ha, consisting of state plantation of 0.69 million ha $(6.89 \%)$, private plantation of 4.90 million ha $(48.95 \%)$ and people's plantation of 4.4 million ha $(44.16 \%)$. Indonesia is the world's largest producer of palm oil, which produces strategic mainstay products and has a very important role in the national economy.

The development of oil palm plantation has received pressure with accusations of being an environment-destroying agent. Oil palm plantation is often referred to as a deforestation agent; this is not always true. Many oil palm plantations are cleared on shrub and other marginal lands. This is supported by research of Gunarso et al. (2012) who has conducted a land cover analysis of Landsat imagery with results showing that in the period of 1990-2010 there was an increase of 6.7 million ha of oil palm plantation from waste land of $43 \%$, agricultural land of $14 \%$, industrial forest estate of $12 \%$. In general, land conditions are degraded land and low-carbon. Therefore, the planting of oil palm plantations in such conditions will increase the ecological function. The presence of oil palm plantations will lower the surface temperature by $0.1237{ }^{\circ} \mathrm{C}$ per year in line with its growth.
The surface temperature will be close to surface temperature in a natural forest, namely 23.04 ${ }^{0} \mathrm{C}$ at the age of 24 years (Rushayati et al., 2017).

Oil palm plantations contribute to the conservation of ecological functions such as the conservation of $\mathrm{CO}_{2}, \mathrm{O}_{2}$ and water $\left(\mathrm{H}_{2} \mathrm{O}\right)$ cycles through the mechanism of photosynthesis and respiration of oil palm plants. Oil palm has an important role in lowering the atmospheric $\mathrm{CO}_{2}$ concentration through $\mathrm{CO}_{2}$ gas absorption in the photosynthesis process. In the photosynthesis process Greenhouse gases $\left(\mathrm{CO}_{2}\right)$ will be absorbed and stored in the $\mathrm{C}$ form in plant biomass. According to Sabiham (2013) in GAPKI (2013), the top carbon stock of oil palm of $<6$ years old is 5.8 tonnes $\mathrm{C} /$ ha and 9-12 years old 54.4 tonnes $\mathrm{C} / \mathrm{ha}$, and $14-15$ years old of 73.0 tonnes $\mathrm{C} / \mathrm{ha}$.

Oil palm plantation managers are required to manage areas that have high conservation value in terms of biodiversity, environmental services, socio-economic and culture. The implementation in the field is by determining protection areas for animals/ plants habitat; the protection of catchment areas, river borders and river, springs, erosion prone and sedimentation areas; the protection of area used to meet daily needs, protection of areas used for cultural activities of local communities.

Oil palm plantation management based on ecology, economy and socio-cultural 
balance will create a harmonious environment. The increased economic growth, maintained environmental conditions, social conditions of the people are also running well. For the global level, Roundtable Sustainable Palm Oil (RSPO) has rolled out a certification scheme for sustainable palm oil plantation management. Similarly, the Government of the Republic of Indonesia has launched a scheme of Indonesia Sustainable Palm Oil (ISPO) which is mandatory for managers of oil palm plantations.

In order to achieve the sustainable oil palm plantation management, all stakeholders involved must have the same vision. Important stakeholders in the effort of mitigating global warming and environmental degradation are the managers of oil palm plantations and the communities around the plantations. No less important is school students around the plantation expected to be a young generation who have knowledge, attitude and behaviour that is environmentally friendly. Collaboration and synergies of oil palm plantations, communities including harmonious school students are vital in creating a good environment. One of the efforts made is through the environmental education.

Environmental education, also known as environmental education (PLH), has evolved since 1972 in response to environmental degradation, namely as a process aimed at developing the world population in order to have awareness and concern for the entire environment and all the problems and who have knowledge, skill, motivation and commitment to work, both individually and collectively to solve current problems and prevent future problems. PLH then develops into various forms of activity with different terms such as Population and Environmental Education, Conservation Education and Education for Sustainable Development.

Various studies have shown that environmental education and its various forms are an effective means for environmental conservation. Education can be an effective means of managing tourist interactions with wildlife and natural environment (Oram, 1997). Students who follow the environmental education have more environmentally friendly behaviours than others, allegedly influenced by the philosophy and ethics given about the harmony of nature and the balance of the ecosystem that causes students' awareness and concern about environmental issues to increase (Isildar and Yildirim, 2008). In line with the study, Howe (2009) also found that the educational conservation as a conservation tool, both through formal and informal education, is a practical and effective conservation intervention. Nevertheless, Howe (2009) emphasised that the success of conservation is also influenced by socio-economic and ecological aspects.

In order to enable the environmental education to be given is correctly targeted and able to change the perception of the target group so as to encourage them to engage in the mitigation efforts of global warming, it is necessary to identify local issues related to global warming as well as the perceptions of target group as the basis for the development of materials and media in the environmental education to be given. This activity is an action research aimed at mitigating global warming with local activities around oil palm plantations through environmental education.

\section{Research Method \\ a. Study Location}

This study was conducted at Oil Palm Plantation, in Kubu Raya District, West Kalimantan Province and its surroundings. The target group of the study were plantation employees, 4th and 5th-grade elementary schools of SD No. 15 Parit Sriwijaya, Sungai Enau, and the community of Sungai Enau Village. The action period was from February to August 2016. The study location is presented in Figure 1. 


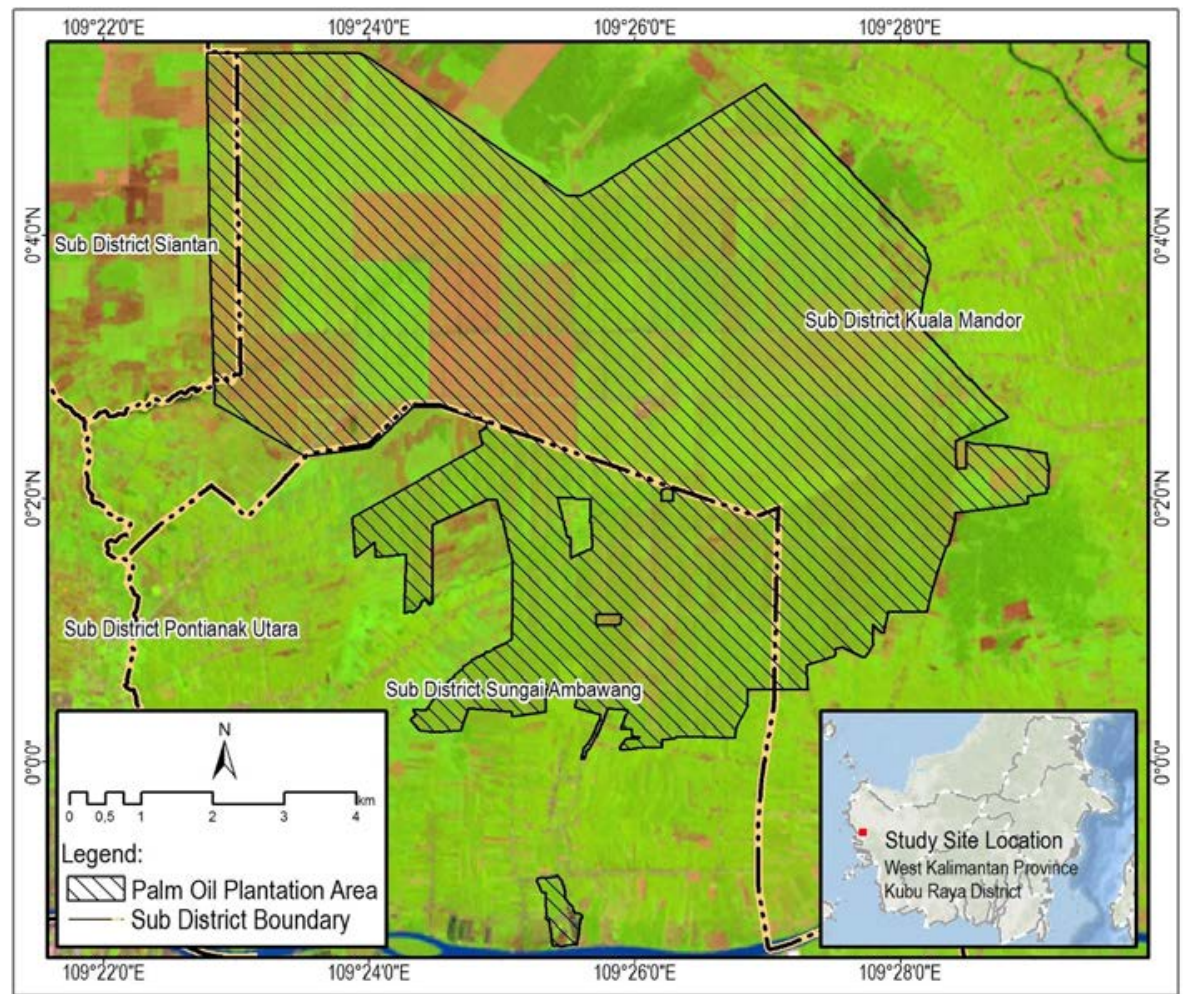

Figure 1. Map of Study Location in Kubu Raya District

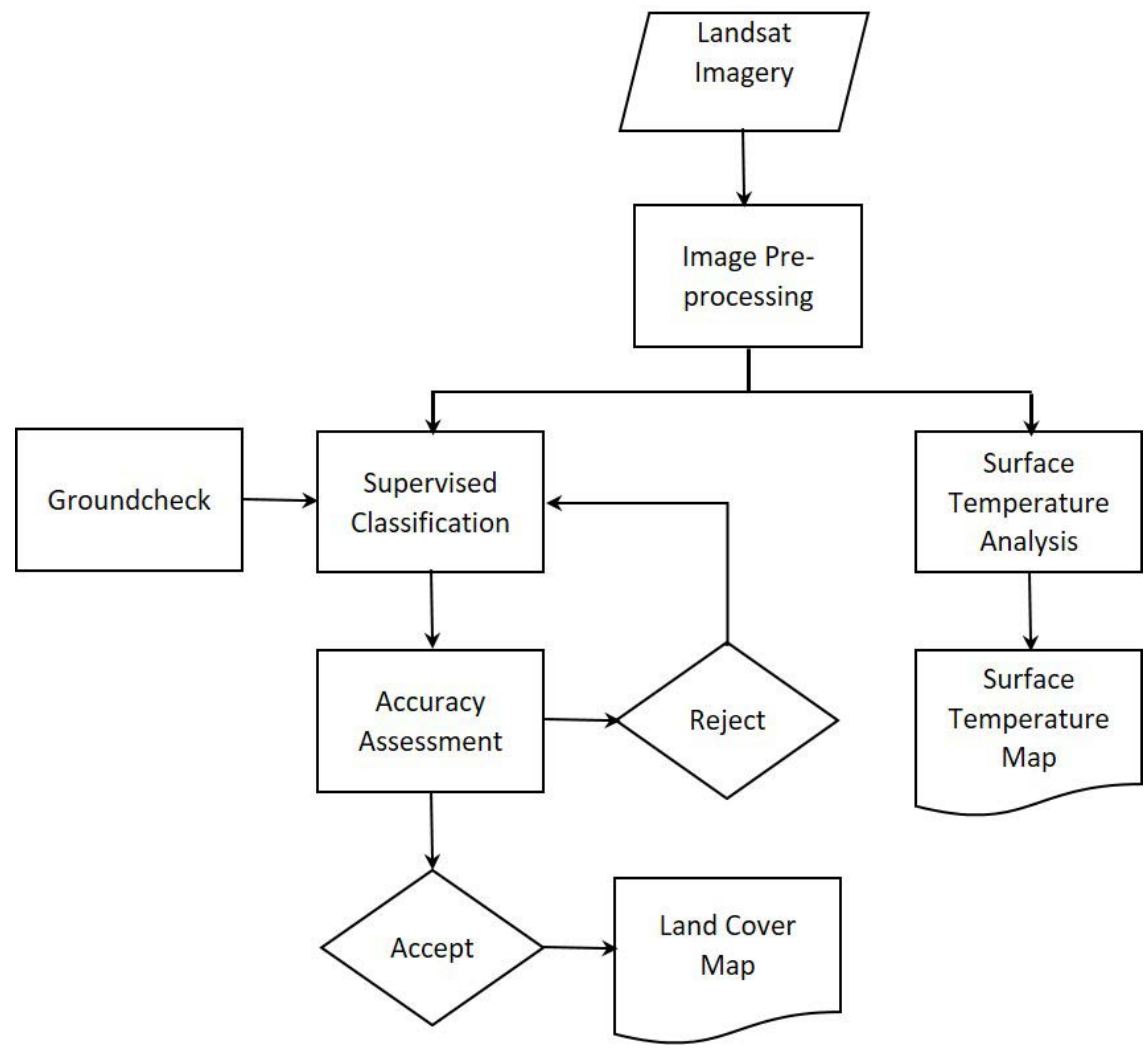

Figure 2. Surface temperature analysis phases flow chart (Rushayati et al., 2017)

\section{b. Study Method}

This study is an action research carried out through several stages: (1) identification of environmental issues related to global warming, (2) identification against the gap of perceptions of the target groups related to global warming, (3) media preparation, (4) dissemination to target groups, and (5) 
analysis of perceptual changes. The surface temperature change analysis is done to verify the result of problem identification through rapid observation and in-depth interview. The identification of environmental problems related to global warming and the gaps of perception of the target group related to the problems are needs assessment which is the basis for determining the material given to the target group.

\section{c. Identification of Environmental Pro- blems}

Data on environmental issues are collected through rapid observation, in-depth interviews and analysis of surface temperature change. The rapid observation is conducted on environmental conditions of Sungai Enau Village and plantation. The in-depth interview is conducted by the plantation manager, plant manager and village head. Descriptive analysis is used by describing the problems found based on observations and interviews.

Any land clearing activity will cause surface temperature change. Similarly, those happen to oil palm plantations. Therefore, this study also conducts a study of surface temperature change in 1989 and 2014 as an attempt to verify the data obtained through the rapid observation and in-depth interview. The surface temperature analysis uses Landsat 5 TM image, while in 2014 Landsat 8 OLI/ TIRS image is used. The analysis is done using Erdas software. Meanwhile, the making of sample point for statistical analysis and layout use ArcGIS 10.3 software.

Prior to analysis of image, image processing is previously conducted. Pre-image processing consists of channel composite, image projection change and image cropping. The channel composite for land cover analysis. The channels used are 1-7 channels. The surface temperature analysis on Landsat 8 used channel 10, while Landsat 5 used channel 6. The projection used is Universal Transverse Mercator (UTM) of zone 49 S. The surface temperature analysis stage is presented in Figure 2.
The analysis of surface temperature change is conducted in several stages. Firstly, it must calculate the spectral radiant value (Equation 1). Then, using Equation 2, the spectral radiant value is converted into temperature in Kelvin (K). After obtaining the value of surface temperature in $\mathrm{K}$ unit, it is converted again using equation 3 , into ${ }^{\circ} \mathrm{C}$. As for the Equations 1, 2 and 3 are presented in the following equation:

\section{$\mathrm{L} \lambda=\mathrm{ML}-\mathrm{Qcal}+\mathrm{AL}$}

\section{Remark:}

$\mathrm{L} \lambda=$ Spectral radian value $(\mathrm{Watt} / \mathrm{m} 2 \mathrm{~s} \mathrm{rad}$ $\mu \mathrm{m})$

ML = Band thermal multiplier specific factor

Qcal $=$ Digital value of band thermal specific image

$\mathrm{AL}=$ Band thermal specific added factor

$\mathrm{Ts}=\mathrm{K} 2 / \ln [(\mathrm{K} 1 / \mathrm{L} \lambda)+1]$

(2)

Remark:

$\mathrm{Ts}=$ Surface temperature $(\mathrm{K})$

$\mathrm{L} \lambda=$ Spectral radian value $($ Watt $/ \mathrm{m} 2 \mathrm{~s} \mathrm{rad}$ $\mu \mathrm{m})$

$\mathrm{K} 1=$ Conversion Constant $1(774.89$ for Landsat 8 and 607.760 for Landsat 5)

$\mathrm{K} 2=$ Conversion Constant 2 (1,321.08 for Landsat 8 and 1260.56 for Landsat 5)

Ts $=$ Ts $(\mathrm{K})-273$

(3)

Remark:

Ts $=$ Surface Temperature $(\mathrm{oC})$

\section{d. Identification of the gap of perception}

The gap of public perception is measured through interviews using questionnaires. Questionnaires are designed based on problems related to global warming found in oil palm plantation and the surrounding villages, especially in Sungai Enau Village. 
Descriptive analysis is used to determine the total score of each respondent and the average score of respondents per target group. In addition, descriptive analysis is also conducted to determine any material needs to be the focus in the dissemination to the target group, i.e. on aspects still poorly understood by the target group with regard to the mitigation of global warming and environmental damage, as indicated by low scores on certain statement items.

\section{e. Preparation of environmental education learning media}

Environmental issues found in the location and the gap of public perception on the issues becomes the basis for material development included in the media learning. The material described in the media focuses on aspects still poorly understood by the target group. Media types are tailored to each target group.

\section{f. Dissemination of environmental edu- cation to target groups}

Dissemination to target groups is conducted with the aim at changing the perception (increase knowledge/ understanding) of the target group on the global warming issues. In the implementation, pre-test and post-test to the target group to identify changes in public perception related to global warming are conducted.

\section{g. Analysis of change in the target group perception}

The change in the target group perception is analysed descriptively and quantitatively by comparing the pre-test and the post-test results. Differences in the pre-test and posttest scores indicate the change in the target group perception on global warming.

\section{Results and Discussion}

\section{a. Environmental issues}

The public recognises the environmental changes, namely in the form of air temperature, and the difficulty of determining the planting period. Some people suffer from floods in the rainy season and drought in the dry season. Rapid observation and interviews conducted to community leaders indicate that there are still unsustainable practices by the community. For example, land preparation and waste management by burning. This shows that in fact, the environmentally unfriendly activities conducted by the community have also contributed to global warming.

According to Harjadi (2016), the vulnerability of an area to disturbance (environmental issues) is determined by internal and external factors. Climate parameters are part of external factors. Currently, air warming and climate change is a global environmental issue and therefore requires a countermeasure involving human. Human knowledge and awareness that human is part of nature are important for human knowledge and awareness to play a role in overcoming environmental issues.

Rushayati et al (2011) said that those dominantly influence the high air temperature is land cover in the form of developed land. Conversely, land cover in the form of vegetation tends to lower the air temperature because through the vegetation photosynthesis process can reduce the concentration of greenhouse gases. Based on the study in the oil palm plantations conducted by Rushayati et al. (2017), it is known that in line with the increased age of vegetation especially oil palm, there is also a decrease in surface temperature.

Based on the spatial analysis of surface temperature, five points were randomly taken from each planting age (age 1 to 15 years). Linear regression was then employed in the analysis. The linear regression formula between the surface temperature and the age of oil palm plantation was $\mathrm{Y}=26.002$ $0.1237 X$. Surface temperature will decrease as much as $0.1237^{\circ} \mathrm{C}$ with one-year oil palm growth.

\section{b. Change in surface temperature}

Based on the spatial analysis of the 
change in surface temperature, it is found that in 1989, the largest area (5,729.0 ha) had a surface temperature range of $21-22{ }^{\circ} \mathrm{C}$. The highest surface temperature was in the range of $23-24{ }^{\circ} \mathrm{C}$. At that time, there was not much land clearing. After 25 years, land clearing got wider; there was an increase in surface temperature. The largest area (3030.4 ha) had a range of $23-24{ }^{\circ} \mathrm{C}$. The highest range also rose, i.e. in the range of $28-29{ }^{\circ} \mathrm{C}$. The wider the open space the higher the surface temperature; it is consistent with the results of a study by Li et al. (2013) which states the relationship between green open space and negative surface temperatures. The less the green open space, the higher the surface temperature; these results reinforce the public statement that mentions the existence of air temperature warming. The changes in the surface temperature from 1989 and 2014, are presented in Figures 3 and 4 and Table 1.

Rushayati (2017) states that land clearing on oil palm plantation concession leads to the increase in surface temperature, but with the increased age of oil palm, the surface temperature is declining due to the absorption of $\mathrm{CO}_{2}$ in the photosynthesis process. The decrease in surface temperature is also due to the higher solar radiation intercepted by the oil palm canopy.

Yulianti et al. (2009) stated that the biomass carbon stock (excluding fresh fruit bunches) of oil palm agroecosystem aged 1 to 18 years ranged from 0.7 to 16.43 tonnes/ha. Based on the study proves that in line with the growth of oil palm, the stored carbon is increasing thus it will lower the surface temperature.

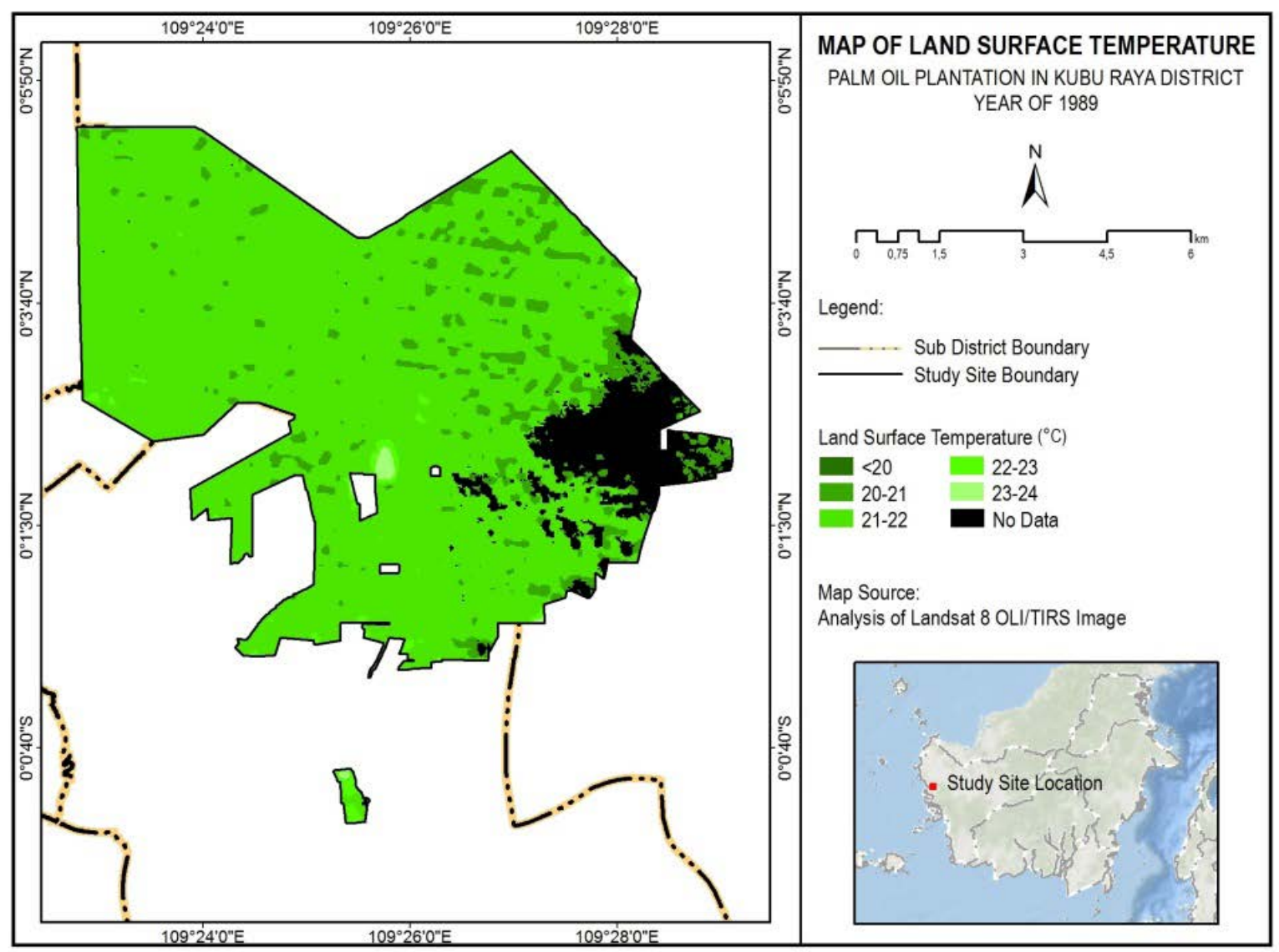

Figure 3. Year 1989 Surface Temperature Map (Rushayati et al., 2017) 


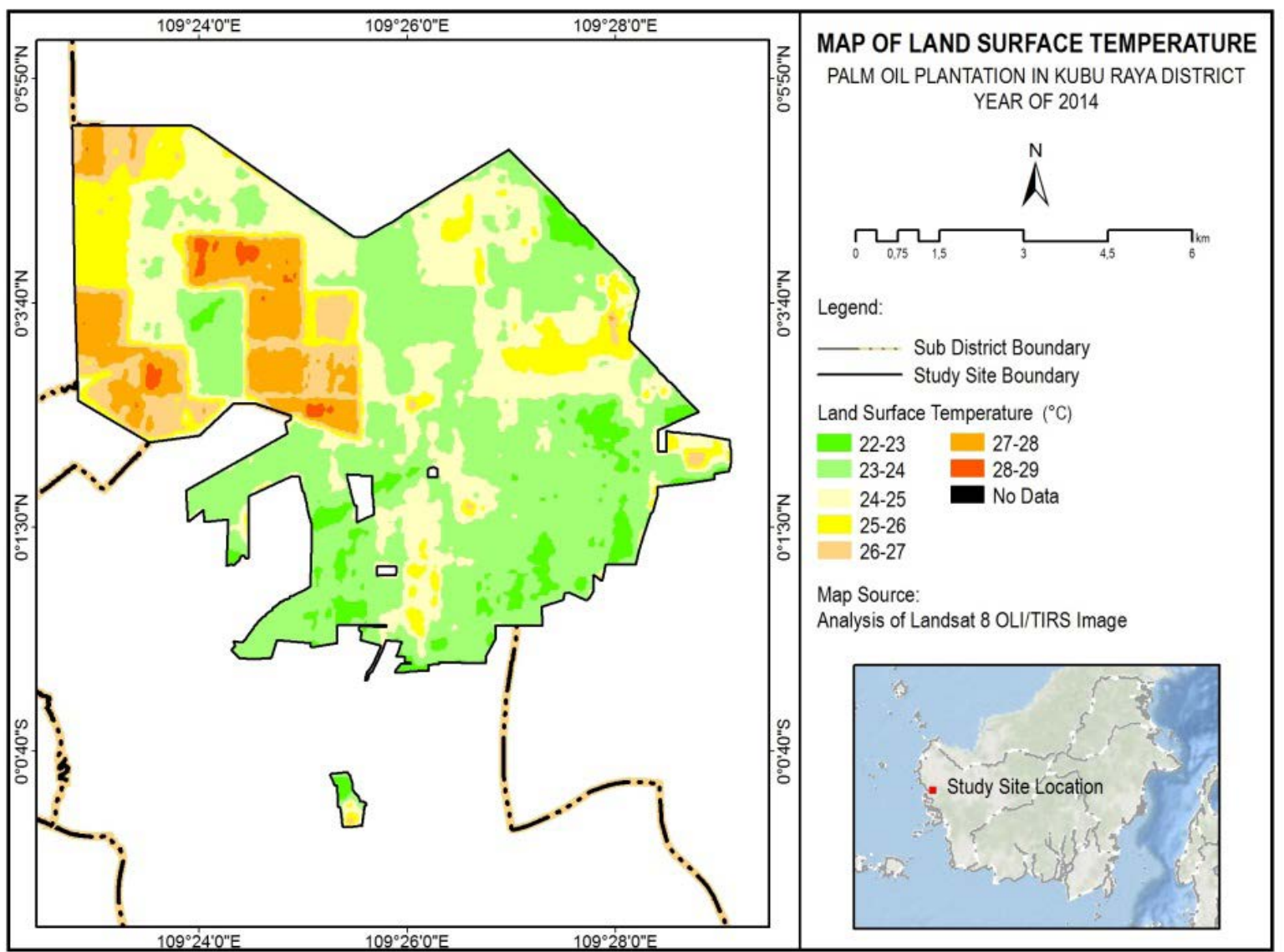

Figure 4. Year 2014 Surface Temperature Map (Rushayati et al., 2017)

Table 1. Area (ha) based on the range of surface temperature $\left({ }^{\circ} \mathrm{C}\right)$

\begin{tabular}{|c|c|c|c|c|c|c|c|c|c|c|c|c|}
\hline \multirow{2}{*}{ Year/ha } & \multicolumn{12}{|c|}{ Surface Temperature $\left({ }^{\circ} \mathrm{C}\right)$} \\
\hline & $<20$ & $20-21$ & $21-22$ & $22-23$ & $23-24$ & 24-25 & $25-26$ & 26-27 & $27-28$ & $28-29$ & 29-30 & $>\mathbf{3 0}$ \\
\hline 1989 & 9.5 & 588.3 & $5,729.0$ & 88.8 & 10.3 & - & - & - & - & - & - & - \\
\hline 2014 & - & - & - & 434.8 & $3,030.4$ & $1,772.6$ & 683.8 & 523.7 & 532.7 & 22.8 & & \\
\hline
\end{tabular}

c. The gap of target group perception

a) Employees of Palm Oil Plantation Company

The results of the questionnaires indicate that the employees of the oil palm plantation companies have understood the importance of environmental preservation, especially in relation to the provisions of RSPO and ISPO. Nevertheless, there is still a need to raise awareness that sustainable environmental management is not merely because of the threat of unsustainable oil palm in international markets, but it has become a necessity and recognised the importance of harmonised oil palm management between economy, ecology and socio-culture. The condition is in line with a study toward oil palm companies in Malaysia carried out by Aikanathan et al. (2015), which showed that companies perceived that they have done enough in sustainability area and land issues and had taken appropriate decision. However, Aikanathan et al. 2015) further explained that there was actually a gap between what the industry perceives and what is actually required for sustainability in managing the industry throughout the palm oil life cycle.

Therefore, environmental education for oil palm plantation employee is needed. The need is strengthened by Yacoob (2007), which stated that one of the barriers to environmental improvements in the palm oil company in Malaysia was low environmental education and outlook amongst employees. 
The environmental education for the employee should focus on strengthening their conservation awareness through the provision of the following subjects:

1. Philosophy and ethics of natural and environmental resources conservation ethics.

2. Implementation of green economy concepts in the sustainable management of oil palm plantation.

3. Principles of conservation and environmental risk assessment in implementing oil palm plantation management.

4. Implementation of high conservation value to control environmental destruction in oil palm plantation.

\section{b) Sungai Enau Village community (parents of students)}

The results show that most community respondents have sensed the current environmental changes indicated by uncertain rain $(83 \%$ of respondents), more frequent/ longer dry season (78\%), lack of water in the dry season $(78 \%)$, increased fire frequency $(94 \%)$ and the difficulty of estimating the planting season $(78 \%)$.

Community knowledge related to environmental management has been good enough, and some has been applied in daily life, namely related to how to overcome the lack of water by storing water (56\%), conserving water use $(17 \%)$, and those who answered the water shortage can be coped with reforestation and greening $(6 \%)$. However, in relation to waste management, most $(78 \%)$ still stated waste management by burning; few (6\%) still stated that garbage was dumped into rivers and some $(22 \%)$ stated making compost. People still thought that burning garbage was a good thing $(61 \%)$.

Most of the respondents (72\%) stated that the people have rules for the utilisation of natural resources, such as the prohibition from illegal logging, burning forests, and utilising natural resources properly. However, some people still stated to open land by burning $(17 \%)$.

The people have a good knowledge of the environment and its issues, but their understanding and behaviour are not fully in line with the knowledge they have. This is in line with Maleki and Karimzadeh (2011) and Fah and Sirisena (2014) finding that knowledge is not always in line with behaviour. It means the subjects for the people needs to be more focused on the consequences of environmental management behaviour undertaken by the community. Therefore, the subject for the community included how to save the earth from global warming and how to plan seedlings correctly. The two subjects is aimed at improving their knowledge on the cause of global warming and the activities that can help saving the earth from global warming, which include planting trees.

\section{c) Elementary students of Sungai Enau}

The average score of students perception about global warming is 9 or $60 \%$ of all questions asked. There are several question numbers answered correctly by less than $60 \%$ of the students. The material relating to the question needs to be the focus of repetition in the provision of dissemination materials. The material deals with global warming and greenhouse effect, the effects of global warming and climate change on the environment, activities that can lead to global warming and good waste management in order not to contribute to global warming.

Students still lack understanding of the causes and efforts to improve global warming and environmental destruction. The average score earned is 9 out of the maximum score of 30 , thus only $30 \%$ of the knowledge has been mastered by the students. There are only two persons who master more than $50 \%$ of the knowledge about the causal factors and efforts to improve global warming and environmental destruction. This includes students with the highest score. Thus, students need to be given materials about the factors causing global warming and environmental destruction, and efforts that can be done to overcome and improve it.

Althoughstudentshaveless understanding of global warming, students have a positive attitude about the activities impacting on the 
environment (Figure 5). The average score of 16 indicates that $80 \%$ of positive views/attitudes are already owned by the students, related to environmental management behaviour, resource use and environmental responsibility.

Considering the result of students perception gap analysis, the environmental education for the students should include topics which would help them understand better the cause of global warming and environmental degradation/destruction, its effect toward human, and how students can help in making a better environment. With these topics, students were expected to be able to explain the cause and effect of global warming, and the measures to deal with global warming.

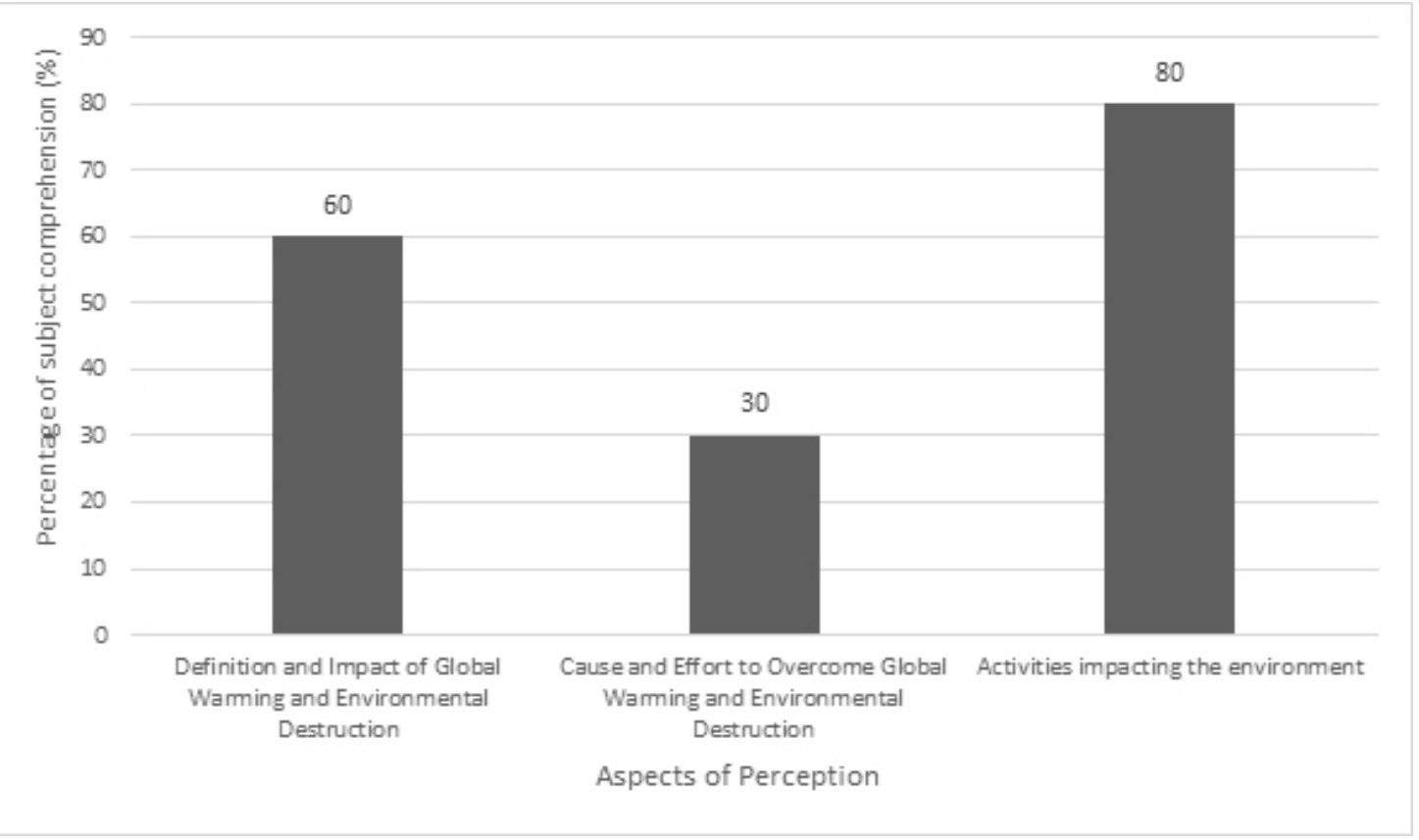

Figure 5. Students' perception of global warming and environmental destruction

Community behaviour is not an easy thing to change because the behaviour is a thing that has become a habit. Kollmus and Agyeman (2002) find that old habits form a very strong barrier to pro-environment behaviour. However, changes in behaviour need to be made by first changing the public perception community through the increased knowledge expected to affect the pattern of action and behaviour of the community to the environment. The focus of material development needs to be directed to things that are still weak, namely:

1. On company employees: environmental ethics and conservation,

2. On community: causes of global warming, and how to overcome them.

3. On elementary school students: the relationship of global warming and the greenhouse effect, the effects of global warming and climate change on the environment, the activities that can lead to global warming, causal factors and efforts to improve global warming.

\section{d. Learning Media}

Learning media is tailored to each target group. Media developed for employees of oil palm plantation companies (plantations and factories) is in the form of modules and power point presentations. The media is considered appropriate for employees who are familiar with training activities using similar media. The modules become materials that employees can learn more, whereas power point presentations are used to give materials in the classroom, with illustrations and material emphasise that can aid understanding of the materials provided. Setiawan et al. (2013) suggest the use of power point media for learning because it can improve learning outcomes of learners. 
Media developed and used for village communities include posters about global warming and posters about planting. Some people (parents of students) are still not proficient in reading, and even they cannot read. The use of posters with drawing illustrations is expected and viewed to help them to understand the materials presented. Osa and Musser (2004) argue that posters are colourful, interesting, environmentally-friendly media that create a more stimulating and interesting environment for learning, and appropriate to illustrate concepts and processes.

Media for elementary students is in the form of global warming and planting posters, modules on environmental destruction and eco-game and recycled paper making tools.
Elementary students from grades 4 and 5 who attend this activity are able to read well, thus the module is developed as a reading material for them. The use of game allows players to internalise the ecological sensitivity of playing the game (Branco et al., 2015). The use of posters with drawing illustrations is expected to help students better understand the materials provided. In addition, a film/ video about environmental destruction in a village downloaded from the internet is also used to stimulate the attention of students and provide examples related to the materials provided. Ahmad et al. (2015) state that the use of video as an instruction medium can provide better understanding and higher awareness of the environment.

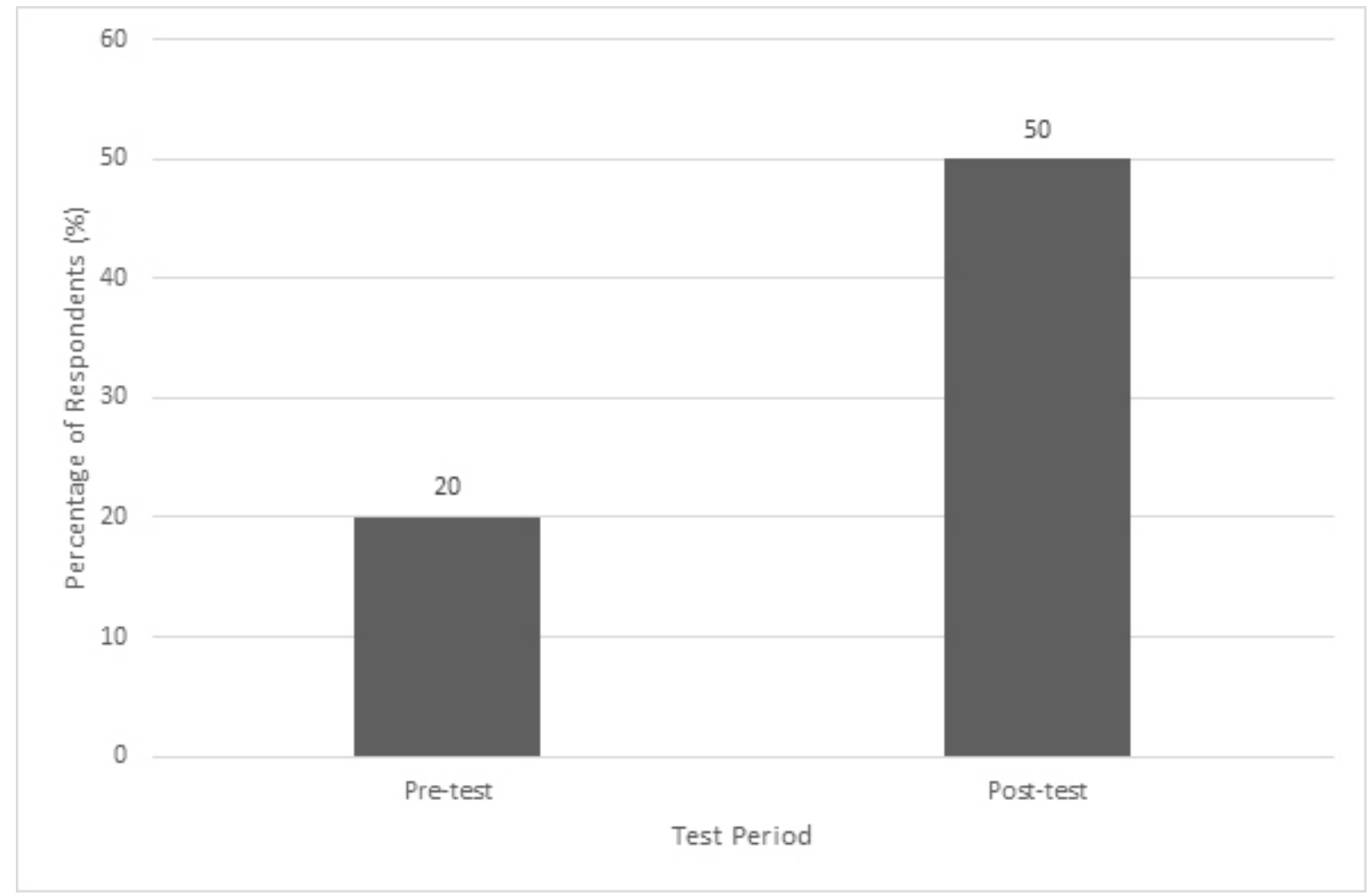

Figure 6. Comparison of respondents (employee) with $>60 \%$ correct answers in pre-test and post-test

e. Change in Target Group Perception

a) Employees of Oil Palm Plantation Companies

The average pre-test score of employees who participated in the dissemination activities is 7.5 (50\% of the total appropriate answers) and the post-test is $10.15(67.67 \%)$, indicating a change in employee perception related to materials provided by 3 points. This means that training/dissemination done can increase the employee knowledge by $20 \%$. Prior to dissemination (pre-test), only $20 \%$ of employees are able to provide the correct answer of $>60 \%$ (Figure 6). The highest pretest score of $13(87 \%$ correct answer) is only obtained by two employees, i.e. employees in 
the field of sustainability and field coordinator.

After the dissemination (post-test), the percentage of employees who can provide the correct answer of $>60 \%$ increases to $50 \%$ (Figure 5). The highest post-test score of 14 (93\% correct answer) is obtained by three employees, namely sustainability person (respondent different from the sustainability employee who obtains the highest pre-test score), one field coordinator and one student/intern.

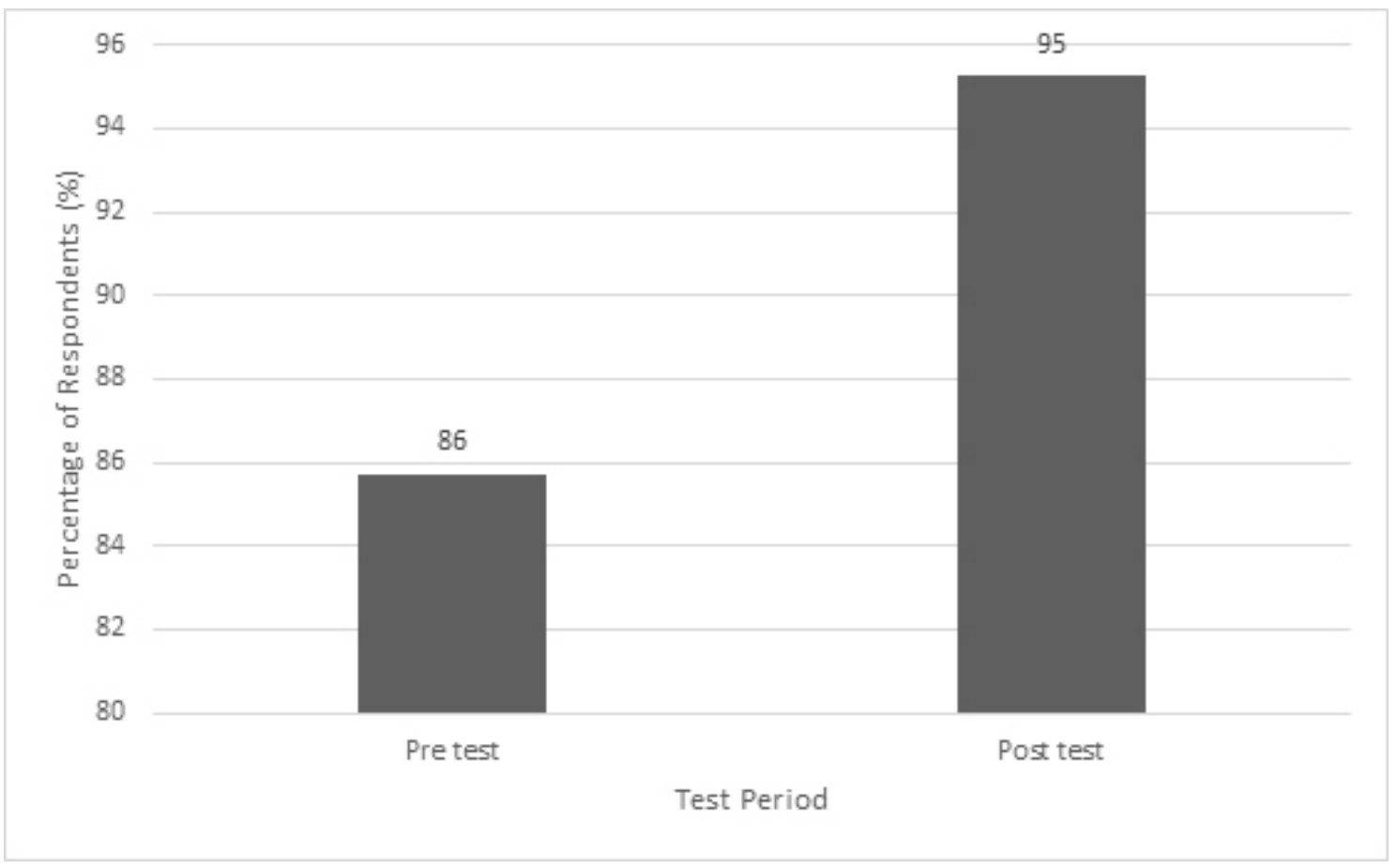

Figure 7. Comparison of respondents (community) with $>60 \%$ correct answers in pre-test and post-test

Materials that are still under-mastered by employees even after participating in dissemination activities related to the meaning of conservation, conservation interests, the reason for saving endangered species, efforts to improve wildlife habitat in relation to the three pillars of conservation, pillars of sustainable development and the meaning of sustainable development and green economy aspects. This means further steps are needed to improve employees' understanding related to the matter.

\section{b) Sungai Enau Village community (parents of students)}

The average score of public perception related to global warming and environmental destruction is already high, even before the activity (pre-test), i.e. 12. After the activity (posttest), the average score increases to 13 , score increase average of $2(13 \%)$. The percentage of respondents who give the correct answer of $>$
$60 \%$ in pre-test is $86 \%$ and increase to $95 \%$ after following dissemination activities (Figure 7).

After the activity, there are 7 respondents who get a score of 15 (100\%), which means all the answers are correct. This indicates a better mastery of the materials provided. Until the end of the activity, there is one question that can be answered correctly only by less than $60 \%$ of respondents, namely question number four related to the cause of forest fires. People still think that the cause of forest fires is a long drought. This shows that people still do not understand the factors that cause forest fires, thus the material still needs reinforcement.

\section{c) Elementary students of Sungai Enau}

Students show a change in perception after attending training activities. The lowest perception score obtained by the students in pre-test is 12 , the highest score 27 , with the average score 19, whereas at the post-test the lowest, highest and average scores are 16, 29, 
and 23 respectively. This means there is an increase of $13 \%$ in perception among students.

Students who are able to provide the correct answer of $>60 \%$ in pre-test are $50 \%$ and increase to $83 \%$ at the post-test (Figure 8). Nevertheless, there is still material that has not been mastered by most students (correct answers are less than $60 \%$ ), i.e. materials related to the effects of global warming on environmental conditions, the impact of forest fire smoke on the environment and the causes of environmental destruction.

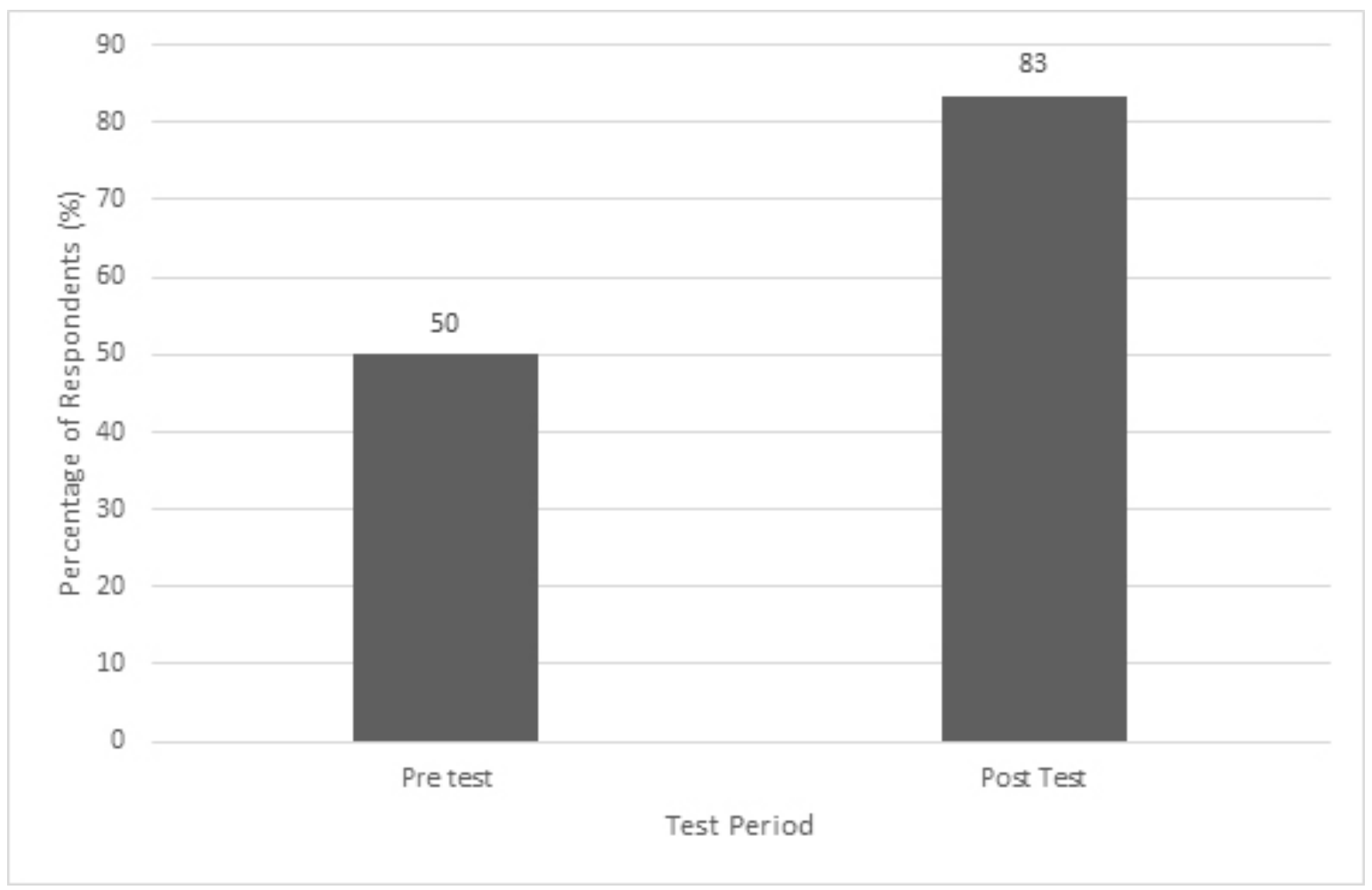

Figure 8. Comparison of respondents (students) with $>60 \%$ correct answers in pre-test and post-test

The perception owned by students does not increase drastically. This can be influenced by several things, namely: (1) long activities (longer than usual school activities) that make students less concentrate on the materials, (2) environmental management habits that have been taking place in the community in everyday life, which has shaped the students perceptions strongly, so it is not easy to change. Nevertheless, the increased student perceptions provide an expectation for the growth of more environmentally friendly behaviours. Knowledge is part of perception. Manolas (2015) states that one of the inhibitors of pro-environmental behaviour is a lack of knowledge. Vicente-Molina et al. (2013) stated that knowledge affects pro-environment behaviour.

People who are environmentally conscious and have environmentally friendly or pro-environment behaviours are needed to maintain environmental functions. But for that, it takes a long process and time. Repetition is needed to strengthen and internalise the understanding in learners (employees, community and students). The opportunity to practice the material obtained needs to be given, thus it can develop a positive new habit. In addition, the implementation of environmental education for the community needs to involve various stakeholders, not only schools, community leaders or oil palm planters but also local government through related agencies.

\section{Conclusions}

Inappropriate environmental management in the area of palm oil plantation can contribute to the global warming-related problems such as air temperature increase, drought and difficulty in determining planting 
season. Based on the serial Landsat Imageries analysis, we found that there is the increased surface temperature in the palm oil area of study between 1989 and 2014. The widest area of surface temperature in 1989 was in the range of $21-22^{\circ} \mathrm{C}$ with an area of $5,729.0 \mathrm{ha}$. The highest surface temperature that occurred in 1989 was in the range of $23-24^{\circ} \mathrm{C}$. The largest area in 2014 was in the range of $23-24^{\circ} \mathrm{C}$ with an area of 3030.4 ha. The highest range in 2014 rose, i.e. $28-29^{\circ} \mathrm{C}$. Environmental destruction in the palm oil plantation activities can contribute to this temperature rising. Therefore, we conducted an environmental education activity as one of the efforts to mitigate the global warming. Dissemination activities conducted, as a whole, can improve the employee (20\%), public (13\%) and students $(13 \%)$ perceptions. Even some individuals can improve scores better, which means this activity helps them to understand better the materials provided. Employees show a greater increase in understanding, although the materials provided is more complex and deeper. However, intensive repetition and assistance are needed to strengthen the target group perception.

\section{References}

Ahmad, J., Sritharan, G., Nasir, N. N. A. M. (2015). The Effectiveness of Video and Pamphlets in Influencing Youth on Environmental Education. Malaysian Journal of Communication 31(1): 281-296.

Aikanathan, S., Basiron, Y., Sundram, K., Chenayah, S., Sasekumar, A. (2015). Sustainable Management of Oil Palm Plantation Industry and the Perception Implications. Journal of Oil Palm, Environment E Health 6:10-24 doi:10.5366/jope.2015.02.

Branco, M. A. A., Weyermüller, A. R., Müller, E. F., Schneider, G. T., Hupffer, H. M., Delgado, J., Mossman, J. B., Bez, M. R., Mendes, T. G. (2015). Games in the environmental context and their strategic use for environmental education. Braz. J. Biol. 75 (2): 114-121

[Ditjen Perkebunan] Direktorat Jenderal Perkebunan. (2014). Statistik Perkebunan Indonesia 20132015 Kelapa Sawit. Ditjen Perkebunan, Jakarta.

Fah, Y. L., Sirisena ,A. (2014). Relationships between the Knowledge, Attitudes, and Behaviour Dimensions of Environmental Literacy: A Structural Equation Modeling Approach Using Smartpls. Jurnal Pemikir Pendidikan (Journal for Educational Thinkers) 5: 119-144, ISSN 19853637 (Print).

[GAPKI] Gabungan Pengusaha Kelapa Sawit Indonesia. (2013). Indonesia dan Perkebunan Kelapa Sawit dalam Isu Lingkungan Global. GAPKI, Jakarta.

Gunarso, P., Hartoyo, M. E., Nugroho, Y., Ristiana, N. I., Maharani, R. S. (2012). Analisis Penutupan Lahan dan Perubahannya Menjadi Kebun Kelapa Sawit di Indonesia Tahun 1990-2010. Tropenbos International Indonesia, Bogor.

Harjadi, B. (2016). Climate Change Vulnerability Analysis of Baluran National Park. Forum Geografi, Vol 30 (2) : 140-149.

Howe, C. (2009). The Role of Education as a Tool for Environmental Conservation and Sustainable Development. [Disertasi]. London (UK): Imperial College London.

Isildar, Y., Yildirim, F. (2008). The Effectiveness of Environmental Education on Environmentally $\square$ Sensitive Behaviors. Education and Science 33(148): 13 - 25.

Kollmus, A., Agyeman, J. (2002). Mind the Gap: why do people act environmentally and what are the barriers to pro-environmental behavior? Environmental Education Research 8 (3): 239-260.

Li, X., Zhou, W., Ouyang, Z. (2013). Relationship between land surface temperature and spatial 
pattern of greenspace: What are the effects of spatial resolution? Landscape and Urban Planning 114: 1-8.

Maleki, A., Karimzadeh, S. (2011). A Survey of Relationship between the Environmental Attitudes and Environmental Knowledge and Energy Consumption Behavior among Citizens of Urmia, West Azerbaijan, Iran. International Journal of Social Sciences and Humanity Studies 3(1): 27-37, ISSN: 1309-8063 (Online).

Manolas, E. (2015). Promoting Pro-environmental Behavior: Overcoming Barriers. AEJES 1: 1321.

Orams, M. B. (1997). The Effectiveness of Environmental Education: Can We Turn Tourists Into 'Greenies'? Progress in Tourism and Hospitality Research 3: 295-306

Osa, J. O., Musser, L. R. (2004). The Role of Posters in Teacher Education Programs. Education Libraries 27 (1) : 16-21.

Rushayati, S. B., Alikodra, H. S., Dahlan, E. N. (2011). Pengembangan Ruang Terbuka Hijau Berdasarkan Distribusi Suhu Permukaan di Kabupaten Bandung. Forum Geografi Vol 25 (1) : 17-26.

Rushayati, S. B., Hermawan, R., Meilani, R. (2017). Age-surface temperature estimation model: When will oil palm plantation reach the same surface temperature as natural forest? IOP Conf. Series: Earth and Environmental Science 54 (2017) 012048.

Setiawan, A., Mulyoto, Yutmini, S. (2013). Pengaruh Media OHP dan Power Point terhadap Hasil Belajar Matematika pada Materi Persamaan Garis Lurus Ditinjau dari Kreatifitas Belajar. Jurnal Teknologi Pendidikan dan Pembelajaran 1 (3): 275 - 288.

Vicente-Molina, M. A., Fernández-Sáinz, A., Izagirre-Olaizola, J. (2013). Environmental knowledge and other variables affecting pro-environmental behaviour: comparison of university students from emerging and advanced countries. Journal of Cleaner Production 61: 130-138.

Yacoob, M. R. (2007). An Investigation of the Malaysian Palm Oil Industry's Environmental Strategies, Stakeholders' Pressure, Environmental Effectiveness and Competitive Advantage. [Dissertation]. University of Newcastle, NSW, Australia.

Yulianti, N., Winarna, Murtilaksana, K. (2009). Perhitungan biomassa dan cadangan karbon dari agroekosistem kelapa sawit, studi kasus di Kebun Meranti Paham dan Panai Jaya, Sumatera Utara. J. Pen. Kelapa Sawit 17(3): 108-113. 